\title{
Ovarian Capsule
}

National Cancer Institute

\section{Source}

National Cancer Institute. Ovarian Capsule. NCI Thesaurus. Code C49265.

A thick connective tissue, called the tunica albuginea, which encapsulates each ovary. 